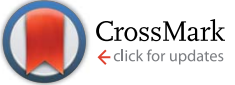

Cite this: RSC Adv., 2017, 7, 15817

\title{
A cancer cell-specific two-photon fluorescent probe for imaging hydrogen sulfide in living cells $\uparrow$
}

\begin{abstract}
Xuezhen Song, Baoli Dong, Xiuqi Kong, Chao Wang, Nan Zhang and Weiying Lin*
Hydrogen sulfide $\left(\mathrm{H}_{2} \mathrm{~S}\right)$ could induce the proliferation of cancer cells in a concentration-dependent manner, and has close relation with the tumor growth. Monitoring the $\mathrm{H}_{2} \mathrm{~S}$ level in real-time is of great important for understanding its roles in the cancer cell proliferation and the diagnosis of the tumor. Herein, a novel cancer cell-specific two-photon fluorescent probe $\mathrm{BN}-\mathrm{H}_{2} \mathrm{~S}$ for detecting $\mathrm{H}_{2} \mathrm{~S}$ in cancer cells was designed and synthesized. Biotin was selected as the cancer cell-specific group and the azide group was employed as the response site for $\mathrm{H}_{2} \mathrm{~S}$. When $\mathrm{BN}-\mathrm{H}_{2} \mathrm{~S}$ responded to $\mathrm{H}_{2} \mathrm{~S}$, a turn-on fluorescence at $544 \mathrm{~nm}$ was observed clearly. BN- $\mathrm{H}_{2} \mathrm{~S}$ exhibited high selectivity for $\mathrm{H}_{2} \mathrm{~S}$ over other relative species. Under the guidance of the biotin group, $\mathrm{BN}-\mathrm{H}_{2} \mathrm{~S}$ can be successfully used for the two-photon imaging of $\mathrm{H}_{2} \mathrm{~S}$ in cancer cells, while $\mathrm{BN}-\mathrm{H}_{2} \mathrm{~S}$ showed relatively weak response for $\mathrm{H}_{2} \mathrm{~S}$ in normal cells. We expect that this design concept can be further developed for selectively detecting other biomolecules in living cancer cells.
\end{abstract}

Received 5th February 2017

Accepted 2nd March 2017

DOI: 10.1039/c7ra01479a

rsc.li/rsc-advances

resolution, non-destructive testing and real-time detection. ${ }^{19-21}$ So far, many fluorescent probes for $\mathrm{H}_{2} \mathrm{~S}$ have been reported. ${ }^{22,23}$ However, to the best of our knowledge, these fluorescent probes all had no cancer cell-specific group and cannot distinguish cancer cells from normal cells. In addition, the two-photon imaging utilizes the long-wavelength light as excitation source, and generally has numerous advantages relative to one-photon imaging, such as reduced photodamage to biosamples and negligible background fluorescence. ${ }^{24,25}$ Therefore, the construction of cancer cell-specific two-photon fluorescent probe for imaging $\mathrm{H}_{2} \mathrm{~S}$ in living system is still in demand.

In this work, we report a novel cancer cell-specific twophoton fluorescent probe $\left(\mathbf{B N}-\mathbf{H}_{2} \mathbf{S}\right)$ for detecting $\mathrm{H}_{2} \mathrm{~S}$. In this probe, biotin was selected as the cancer cell-specific group, because the receptors related to the uptake of biotin are generally overexpressed on the cancer cell surface. Accordingly, BN- $\mathrm{H}_{2} \mathbf{S}$ could discriminate the cancer cells from normal cells under the guidance of biotin group. The probe $\mathbf{B N}-\mathbf{H}_{2} \mathbf{S}$ has excellent sensitivity and selectivity for detecting $\mathrm{H}_{2} \mathrm{~S}$. The bioimaging experiments demonstrate that $\mathbf{B N}-\mathbf{H}_{2} \mathbf{S}$ could be applied for the two-photon fluorescence imaging of $\mathrm{H}_{2} \mathrm{~S}$ in living cancer cells.

\section{Experimental}

\subsection{Materials and instruments}

All chemical reagents were commercial. Twice-distilled water was used in all the experiments. Thin Layer Chromatography (TLC) analysis was performed on the silica gel plates and the chromatography was performed using silica gel (mesh 200-300, Qingdao Ocean Chemicals). NMR spectra were obtained on an AVANCE III $400 \mathrm{MHz}$ Digital NMR Spectrometer, and 
tetramethylsilane (TMS) was used as internal reference. Highresolution electronspray mass spectra (HRMS) were obtained from a Bruker APEX IV-FTMS 7.0T mass spectrometer. $\mathrm{pH}$ values were determined on a Mettler-Toledo Delta $320 \mathrm{pH}$ meter. UV-vis absorption spectra were measured on a Shimadzu UV-2600 spectrophotometer. Fluorescence spectra were obtained with a Hitachi F4600 fluorescence spectrophotometer. HeLa cells, NIH 3T3 cells and calf bovine serum were obtained from the College of Life Science, Nankai University (Tianjin, China).

\subsection{Synthesis of compound 2}

Compound 1 was synthesized according to the previous report. ${ }^{26} \mathrm{~A}$ mixture of compound 1 (636 $\mathrm{mg}, 2 \mathrm{mmol}$ ), biotin (488.62 mg, $2 \mathrm{mmol}$ ), EDCl (576 mg, $3 \mathrm{mmol}$ ), HOBt (675 g, 5 mmol) and DIEA ( $1 \mathrm{~mL})$ in DMF (3 mL) was stirred for $12 \mathrm{~h}$ at room temperature. Then $6 \mathrm{~mL}$ water was added into the mixture and extracted with $\mathrm{CH}_{2} \mathrm{Cl}_{2}$, washed three times with water, dried over $\mathrm{Na}_{2} \mathrm{SO}_{4}$ and evaporated under reduced pressure to provide crude compound 2 . Then the crude product was purified by silica column chromatography $\left(\mathrm{CH}_{2} \mathrm{Cl}_{2}: \mathrm{MeOH}=10: 1\right)$ to afford compound 2 (380 mg, yield 35\%). ${ }^{1} \mathrm{H}$ NMR (DMSO- $d_{6}$, $400 \mathrm{MHz}): \delta 8.54-8.57(\mathrm{~m}, 2 \mathrm{H}), 8.33-8.35(\mathrm{~d}, J=8.0 \mathrm{~Hz}, 1 \mathrm{H})$, $8.22-8.24(\mathrm{~d}, J=8.0 \mathrm{~Hz}, 1 \mathrm{H}), 8.01-8.03(\mathrm{t}, 1 \mathrm{H}), 7.91-7.99(\mathrm{t}, 1 \mathrm{H})$, 6.38-6.42 (d, $J=20.0 \mathrm{~Hz}, 2 \mathrm{H}), 4.29-4.32(\mathrm{~m}, 1 \mathrm{H}) 4.11-4.14(\mathrm{t}$, $2 \mathrm{H})$, 4.04-4.07 (m, 1H), 2.94-2.99 (m, 1H), 2.78-2.82 (m, 1H), 2.56-2.59 (m, 1H), 1.91-1.94 (m, 2H), 1.55-1.56 (m, 1H), 1.381.40 (m, 3H), 1.19-1.21 (m, 3H). ${ }^{13} \mathrm{C}$ NMR (DMSO- $d_{6}, 100 \mathrm{MHz}$ ): $172.77,163.60,163.55,163.15,132.96,131.96,131.82,131.35$, $130.29,129.42,129.29$, 128.95, 123.48, 122.71, 61.43, 59.66, $55.81,36.68,35.69,28.55,28.44,25.61$. HRMS (ESI): $m / z$ calculated for $\mathrm{C}_{24} \mathrm{H}_{25} \mathrm{BrN}_{4} \mathrm{O}_{5} \mathrm{~S}[\mathrm{M}+\mathrm{H}]^{+}$545.0780, found: 545.0826 .

\subsection{Synthesis of $\mathrm{BN}-\mathrm{H}_{2} \mathrm{~S}$}

Compound 2 (272 mg, $0.5 \mathrm{mmol}$ ), $\mathrm{NaN}_{3}$ (65 mg, $1 \mathrm{mmol}$ ) were mixed in DMF $(5.0 \mathrm{~mL})$ and stirred at $50{ }^{\circ} \mathrm{C}$ for $4 \mathrm{~h}$. Then $5 \mathrm{~mL}$ water was added into the mixture and extracted with $\mathrm{CH}_{2} \mathrm{Cl}_{2}$, washed three times with water, dried over $\mathrm{Na}_{2} \mathrm{SO}_{4}$ and evaporated under reduced pressure. The crude product was purified by silica column chromatography $\left(\mathrm{CH}_{2} \mathrm{Cl}_{2}: \mathrm{MeOH}=5: 1\right)$ to afford $\mathbf{B N}-\mathbf{H}_{2} \mathbf{S}\left(147 \mathrm{mg}\right.$, yield $58 \%$ ) as an orange-yellow solid. ${ }^{1} \mathrm{H}$ NMR (DMSO- $\left.d_{6}, 400 \mathrm{MHz}\right): \delta 8.56-8.59(\mathrm{~m}, 1 \mathrm{H}), 8.43-8.48(\mathrm{~m}$, $1 \mathrm{H}), 8.23-8.36(\mathrm{~m}, 1 \mathrm{H}), 7.84-8.04(\mathrm{~m}, 2 \mathrm{H}), 7.27-7.38(\mathrm{~m}, 1 \mathrm{H})$, 6.38-6.42 (d, $J=20.0 \mathrm{~Hz}, 2 \mathrm{H}), 4.29-4.32(\mathrm{t}, 1 \mathrm{H}), 4.11-4.14(\mathrm{t}$, $2 \mathrm{H}), 4.05-4.06(\mathrm{~s}, 1 \mathrm{H}), 2.97-2.99(\mathrm{t}, 1 \mathrm{H}), 2.78-2.82(\mathrm{~m}, 1 \mathrm{H}), 1.91-$ $1.94(\mathrm{~m}, 2 \mathrm{H}), 1.48-1.53(\mathrm{~m}, 1 \mathrm{H}), 1.35-1.39(\mathrm{~m}, 3 \mathrm{H}), 1.18-1.24$ $(\mathrm{m}, 4 \mathrm{H}), 0.82-0.87(\mathrm{~m}, 1 \mathrm{H}) .{ }^{13} \mathrm{C}$ NMR (DMSO- $\left.d_{6}, 100 \mathrm{MHz}\right)$ : $172.65,164.48,163.58,163.20,153.10,134.32,131.38,130.28$, 129.72 , 124.39, 122.41, 119.82, 108.53, 108.15, 61.40, 59.66, $55.81,36.98,35.72,34.64,28.53,28.41,25.62$. HRMS (ESI): $\mathrm{m} / \mathrm{z}$ calculated for $\mathrm{C}_{24} \mathrm{H}_{25} \mathrm{~N}_{7} \mathrm{O}_{4} \mathrm{~S}[\mathrm{M}+\mathrm{H}]^{+}$508.1761, found 508.1758.

\subsection{Synthesis of $\mathrm{BN}-\mathrm{NH}_{2}$}

The mixture of $\mathbf{B N}-\mathbf{H}_{2} \mathbf{S}$ (51 mg, $0.1 \mathrm{mmol}$ ) and $\mathrm{Na}_{2} \mathrm{~S}$ (39 mg, 0.5 $\mathrm{mmol}$ ) in $2 \mathrm{~mL} \mathrm{DMF}$ was stirred to room temperature for $6 \mathrm{~h}$. Then $5 \mathrm{~mL}$ water was added into the mixture and extracted with
$\mathrm{CH}_{2} \mathrm{Cl}_{2}$, washed three times with water, dried over $\mathrm{Na}_{2} \mathrm{SO}_{4}$ and evaporated under reduced pressure. The solid residue was purified by flash chromatography column using methanol/ dichloromethane (v/v $1: 10)$ to afford a yellow solid as $\mathbf{B N}$ $\mathbf{N H}_{2}\left(36 \mathrm{mg}\right.$, yield 75\%). ${ }^{1} \mathrm{H}$ NMR (DMSO- $d_{6}, 400 \mathrm{MHz}$ ): $\delta$ 8.61$8.63(\mathrm{~d}, 1 \mathrm{H}), 8.42-8.44(\mathrm{~d}, 1 \mathrm{H}), 8.18-8.20(\mathrm{~d}, 1 \mathrm{H}), 7.87-7.90(\mathrm{t}$, $1 \mathrm{H}), 7.64-7.68(\mathrm{t}, 1 \mathrm{H}), 7.45(\mathrm{~s}, 2 \mathrm{H}), 6.83-6.85(\mathrm{~d}, J=8.0 \mathrm{~Hz}, 1 \mathrm{H})$, $6.38-6.43(\mathrm{~d}, J=20.0 \mathrm{~Hz}, 2 \mathrm{H}), 4.29-4.32(\mathrm{t}, 1 \mathrm{H}), 4.03-4.12(\mathrm{~m}$, $3 \mathrm{H}), 2.95-2.99(\mathrm{~m}, 1 \mathrm{H}), 2.78-2.82(\mathrm{~m}, 1 \mathrm{H}), 2.58$ (s, 1H), 1.93-1.97 $(\mathrm{t}, 2 \mathrm{H}), 1.50-1.53(\mathrm{~m}, 1 \mathrm{H}), 1.38-1.44(\mathrm{~m}, 3 \mathrm{H}), 1.19-1.22(\mathrm{~m}, 3 \mathrm{H})$, 0.82-0.87 (m, 1H). ${ }^{13} \mathrm{C}$ NMR (DMSO- $\left.d_{6}, 100 \mathrm{MHz}\right): 172.74$, 163.93 , 163.56, 163.17, 143.18, 132.98, 131.97, 131.37, 128.93, $127.77,124.00,122.84,118.86,116.40,63.43,59.65,55.82$, $36.73,35.69,30.23,29.10,23.46,23.09$. HRMS (ESI): $\mathrm{m} / \mathrm{z}$ calculated for $\mathrm{C}_{24} \mathrm{H}_{27} \mathrm{~N}_{5} \mathrm{O}_{4} \mathrm{~S}[\mathrm{M}+\mathrm{H}]^{+}$482.1857, found 482.1861; [M + $\mathrm{Na}]^{+}$504.1681, found 504.1675.

\subsection{Determination of fluorescence quantum yield}

Fluorescence quantum yields were determined using Rhodamine-6G as reference $\left(\Phi_{\mathrm{f}}=0.94\right.$ in ethanol). The quantum yields were calculated following the equation: $\Phi_{\mathrm{S}}=\Phi_{\mathrm{R}}$ $\times\left(I_{\mathrm{S}} / I_{\mathrm{R}}\right) \times\left(A_{\mathrm{R}} / A_{\mathrm{S}}\right) \times\left(\eta_{\mathrm{S}} / \eta_{\mathrm{R}}\right)^{2}$. Here, $\Phi_{\mathrm{S}}$ and $\Phi_{\mathrm{R}}$ are the quantum yields of sample and reference, $I_{\mathrm{S}}$ and $I_{\mathrm{R}}$ are the integrated emission intensities of the corrected spectra for the sample and reference, $A_{\mathrm{R}}$ and $A_{\mathrm{S}}$ stand for the absorbance of the reference and sample at the excitation wavelength, $\eta_{\mathrm{S}} / \eta_{\mathrm{R}}$ are the values of refractive index for the respective solvent used for the sample and reference.

\subsection{Measurements of two-photon cross section}

Two-photon cross sections $(\delta)$ for $\mathbf{B N}-\mathbf{H}_{2} \mathbf{S}$ in absence and presence of $\mathrm{Na}_{2} \mathrm{~S}$ in PBS (20 mM, pH $\left.=7.4,5 \% \mathrm{MeOH}\right)$ were determined following the previously reported methods, and Rhodamine 6G was selected as the reference. ${ }^{27}$ The two-photon absorption cross section $(\delta)$ was calculated using the equation: $\delta=\delta_{\mathrm{r}}\left(S_{\mathrm{s}} \Phi_{\mathrm{r}} \phi_{\mathrm{r}} c_{\mathrm{r}}\right) /\left(S_{\mathrm{r}} \Phi_{\mathrm{s}} \phi_{\mathrm{s}} c_{\mathrm{s}}\right)$, where the subscripts s and $\mathrm{r}$ stand for the sample and reference molecule, $S$ is the intensity of the signal collected using a CCD detector. $\Phi$ is the fluorescence quantum yield, and $\phi$ stands for the overall fluorescence collection efficiency of the experimental apparatus. $c$ is the concentration, and $\delta_{\mathrm{r}}$ is the two-photon absorption cross section of Rhodamine $6 \mathrm{G}$.

\subsection{Cytotoxicity experiments}

Cytotoxic effects of $\mathbf{B N}-\mathbf{H}_{2} \mathbf{S}$ were evaluated using the MTT assay. HeLa and NIH 3T3 cells were seeded into 96 well-plates at the density of 3000 cells per well. After $24 \mathrm{~h}$ of cell attachment, various concentrations of $\mathbf{B N}-\mathbf{H}_{2} \mathbf{S}$ were added into wells for the further cultured of $24 \mathrm{~h}$. Then, $10 \mu \mathrm{L}$ of MTT $(5 \mu \mathrm{g}$ $\mathrm{mL}^{-1}$ ) were mixed into cells for incubated another $4 \mathrm{~h}$. After that, $100 \mu \mathrm{L}$ of DMSO were used to resolve the formazan. The plate was shaken for $20 \mathrm{~min}$, and then the absorbance was determined at $570 \mathrm{~nm}$ by a microplate reader (Thermo Fisher Scientific). Cell viability was expressed as a percentage of the control culture value. 


\subsection{Cell culture and fluorescence imaging}

HeLa and NIH 3T3 cells were cultured in modified Eagle's medium supplemented with $10 \%$ calf bovine serum in an atmosphere of $5 \% \mathrm{CO}_{2}$ and $95 \%$ air at $37{ }^{\circ} \mathrm{C}$. The cells were seeded into the glass-bottom culture dishes and cultured for $24 \mathrm{~h}$. For the imaging of $\mathrm{Na}_{2} \mathrm{~S}$, the cells were incubated with 10 $\mu \mathrm{M} \mathbf{B N}-\mathrm{H}_{2} \mathbf{S}$ for $15 \mathrm{~min}$ at $37^{\circ} \mathrm{C}$, then the media was replaced with PBS. The cells were then incubated with $\mathrm{Na}_{2} \mathrm{~S}$ for another $30 \mathrm{~min}$, and then the imaging was performed using a Nikon A1R $\mathrm{MP}+$ confocal microscope.

\section{Results and discussion}

\subsection{Design and synthesis of $\mathrm{BN}-\mathrm{H}_{2} \mathrm{~S}$}

As shown in Scheme 1, the designed probe $\mathbf{B N}-\mathbf{H}_{2} \mathbf{S}$ was made of three factors including cancer cell-specific group, two-photon fluorophore and $\mathrm{H}_{2} \mathrm{~S}$ response site. Initially, biotin was selected as the cancer cell-specific group, because the receptors related to the uptake of biotin are generally overexpressed on the cancer cell surface to sustain the rapid growth of the cancer cells, and the biotin can be chemically modified easily. Previously, many studies also demonstrated that biotin could be used as a cancer-targeting molecule. ${ }^{28,29}$ Naphthalimide fluorophore was employed as the two-photon fluorophore due to its significant advantages in optical properties, including excellent photostability, high fluorescence quantum yield and desirable two-photon emission properties. In addition, the azide group was employed as the response site because of its highly selective and sensitive response for $\mathrm{H}_{2} \mathrm{~S}$. With these considerations in mind, we constructed a biotin-guided twophoton fluorescent probe $\mathbf{B N}-\mathbf{H}_{2} \mathbf{S}$ for detecting $\mathrm{H}_{2} \mathrm{~S}$. NA- $\mathbf{H}_{2} \mathbf{S}$ has no biotin group was selected as the control compound, and was synthesized according to the previous report. ${ }^{30}$ The synthesis route of $\mathbf{B N}-\mathbf{H}_{2} \mathbf{S}$ was shown in Scheme 1, and the structure was determined by HRMS, ${ }^{1} \mathrm{H}$ NMR and ${ }^{13} \mathrm{C}$ NMR spectra (ESI $\dagger$ ).

\subsection{Optical response of $\mathrm{BN}-\mathrm{H}_{2} \mathrm{~S}$ to $\mathrm{H}_{2} \mathrm{~S}$}

Initially, we determined the optical response of $\mathbf{B N}-\mathbf{H}_{2} \mathbf{S}$ to $\mathrm{H}_{2} \mathrm{~S}$ in PBS (20 mM, pH = 7.4, 5\% $\mathrm{MeOH})$ using UV-vis absorption
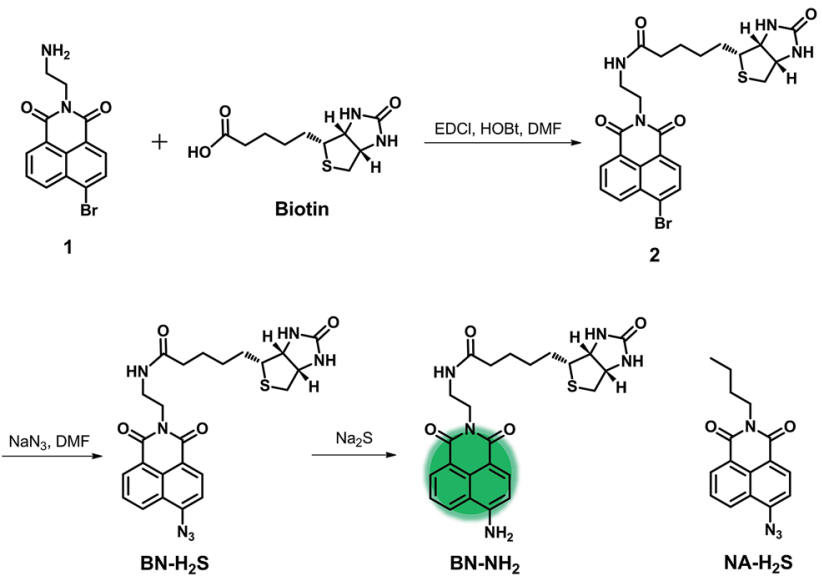

Scheme 1 Synthesis route of $\mathrm{BN}-\mathrm{H}_{2} \mathrm{~S}$ and chemical structure of NA$\mathrm{H}_{2} \mathrm{~S}$.

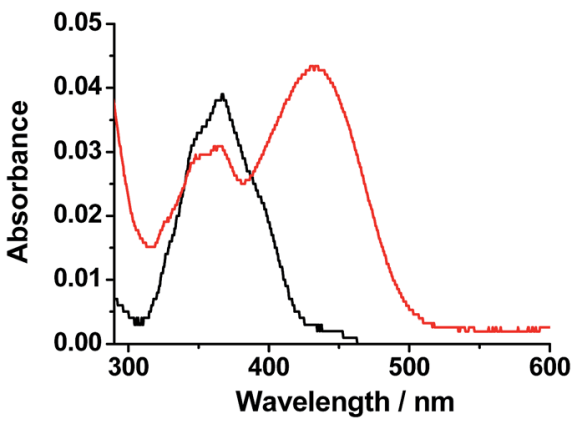

Fig. 1 Absorption spectra of $5 \mu \mathrm{M} \mathrm{BN}-\mathrm{H}_{2} \mathrm{~S}$ in absence (black) and presence (red) of $100 \mu \mathrm{M} \mathrm{Na}_{2} \mathrm{~S}$ in PBS $(20 \mathrm{mM}, \mathrm{pH}=7.4,5 \% \mathrm{MeOH})$.

spectra. $\mathrm{Na}_{2} \mathrm{~S}$ was selected as $\mathrm{H}_{2} \mathrm{~S}$ source. As shown in Fig. $1, \mathbf{B N}$ $\mathbf{H}_{2} \mathbf{S}$ exhibited a main absorption maximum at $366 \mathrm{~nm}$ with molar absorption coefficient $(\varepsilon)$ of $0.77 \times 10^{4} \mathrm{M}^{-1} \mathrm{~cm}^{-1}$ arised from the naphthalimide fluorophore. Upon the addition of $\mathrm{Na}_{2} \mathrm{~S}$, the absorbance at $366 \mathrm{~nm}$ decreased and a new absorption at $432 \mathrm{~nm}$ appeared, indicating that the reaction between BN- $\mathrm{H}_{2} \mathrm{~S}$ and $\mathrm{H}_{2} \mathrm{~S}$ indeed occurred.

Subsequently, the optical response of $\mathbf{B N}-\mathbf{H}_{2} \mathbf{S}$ to $\mathrm{H}_{2} \mathrm{~S}$ in PBS was investigated using fluorescence spectra. As shown in Fig. 2, $\mathbf{B N}-\mathbf{H}_{2} \mathbf{S}$ itself showed weak fluorescence under the excitation at $440 \mathrm{~nm}$ with the fluorescence quantum yield $(\Phi)$ of 0.01 . Upon the addition $\mathrm{Na}_{2} \mathrm{~S}$, the fluorescence intensity at $544 \mathrm{~nm}$ increased gradually with raising the $\mathrm{Na}_{2} \mathrm{~S}$ concentration, corresponding to the fluorescent color of $\mathbf{B N}-\mathbf{H}_{2} \mathbf{S}$ solution changed from weak green to strong green after the addition of $\mathrm{Na}_{2} \mathrm{~S}$ under the irradiation of $365 \mathrm{~nm}$ ultraviolet light. An excellent linearity between the fluorescence intensity at $544 \mathrm{~nm}$ and $\mathrm{Na}_{2} \mathrm{~S}$ concentration in the range of $0-80 \mu \mathrm{M}$ was observed, and the detection limit was calculated to $71 \mathrm{nM}(\mathrm{S} / \mathrm{N}=3)$ according to IUPAC recommendations. Therefore, $\mathbf{B N}-\mathbf{H}_{2} \mathbf{S}$ has highly sensitivity and can potentially be applied for detecting $\mathrm{H}_{2} \mathrm{~S}$ in living system.

The response mechanism of $\mathbf{B N}-\mathbf{H}_{2} \mathbf{S}$ to $\mathrm{H}_{2} \mathrm{~S}$ was further explored on the basis of the HRMS data and the reaction experiment of $\mathbf{B N}-\mathbf{H}_{2} \mathbf{S}$ and $\mathrm{Na}_{2} \mathrm{~S}$. The azide group can be liable to be reduced to amino by $\mathrm{H}_{2} \mathrm{~S}$ chemically, and the response
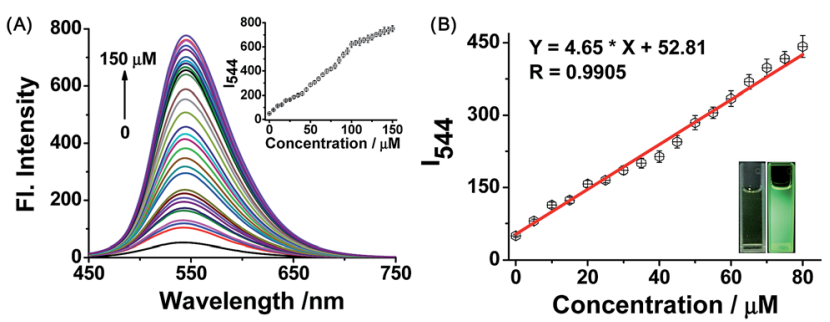

Fig. 2 (A) Fluorescence spectra of $5 \mu \mathrm{M} \mathrm{BN}-\mathrm{H}_{2} \mathrm{~S}$ upon the addition of 0-150 $\mu \mathrm{M} \mathrm{Na}_{2} \mathrm{~S}$ in PBS ( $20 \mathrm{mM}, \mathrm{pH}=7.4,5 \% \mathrm{MeOH}$ ) with the excitation at $440 \mathrm{~nm}$, inset: the fluorescence intensity at $544 \mathrm{~nm}$ as a function of $\mathrm{Na}_{2} \mathrm{~S}$ concentration. (B) Linearity between the fluorescence intensity at $544 \mathrm{~nm}$ and $\mathrm{Na}_{2} \mathrm{~S}$ concentration in the range of $0-$ $80 \mu \mathrm{M}$, inset: images of $5 \mu \mathrm{M} \mathrm{BN}-\mathrm{H}_{2} \mathrm{~S}$ in absence (left) and presence (right) of $100 \mu \mathrm{M} \mathrm{Na}_{2} \mathrm{~S}$ under a UV lamp at $365 \mathrm{~nm}$. 


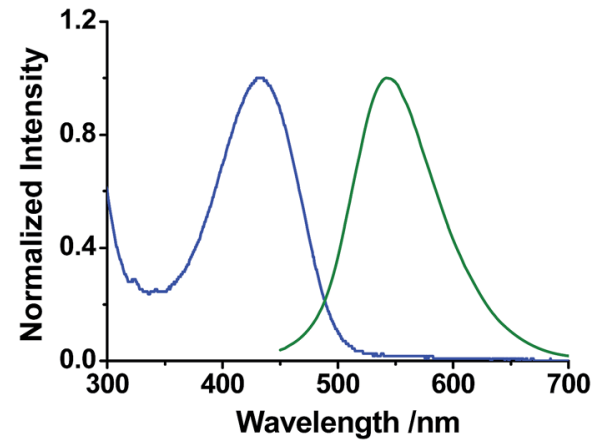

Fig. 3 Normalized absorption (blue) and fluorescence spectra (green, $\lambda_{\text {ex }}=440 \mathrm{~nm}$ ) of $5 \mu \mathrm{M} \mathrm{BN}-\mathrm{NH}_{2}$ in PBS (pH 7.4, $\left.20 \mathrm{mM}, 5 \% \mathrm{MeOH}\right)$.

mechanism of $\mathbf{B N}-\mathbf{H}_{2} \mathbf{S}$ to $\mathrm{H}_{2} \mathrm{~S}$ was proposed to be based on the reduction of nitrine (Scheme $\mathrm{S} 1 \dagger$ ). As shown in the HRMS assay (Fig. S1 $\dagger$ ), the two peaks at 482.1861 and 504.1671 corresponding to $\mathbf{B N}-\mathbf{N H}_{2}$ (calcd $[\mathrm{M}+\mathrm{H}]^{+}, 482.1857$ and $[\mathrm{M}+\mathrm{Na}]^{+}$, 504.1681 ) were clearly observed, indicating that $\mathbf{B N}-\mathbf{H}_{2} \mathbf{S}$ can be reduced to $\mathbf{B N}-\mathbf{N H}_{2}$ in PBS. Meanwhile, $\mathbf{B N}-\mathbf{H}_{2} \mathbf{S}$ can react with $\mathrm{Na}_{2} \mathrm{~S}$ in DMF for $6 \mathrm{~h}$, to afford the product $\mathbf{B N}-\mathbf{N H}_{2}$ with a yield of $75 \%$ (Scheme 1). $\mathbf{B N}-\mathbf{N H}_{2}$ displayed the main absorption at $432 \mathrm{~nm}$ and fluorescence at $544 \mathrm{~nm}(\Phi=0.29)$ under excitation at $440 \mathrm{~nm}$ in PBS, consisting well with the absorption and fluorescence spectra of $\mathbf{B N}-\mathbf{H}_{2} \mathbf{S}$ after responding to $\mathrm{Na}_{2} \mathrm{~S}$ (Fig. 3). Therefore, the response mechanism of $\mathbf{B N}-\mathbf{H}_{2} \mathbf{S}$ to $\mathrm{H}_{2} \mathrm{~S}$ was proposed to base on the reduction of azide group.

The selectivity of $\mathbf{B N}-\mathbf{H}_{2} \mathrm{~S}$ to $\mathrm{H}_{2} \mathrm{~S}$ was evaluated by determining the fluorescence spectra of $\mathbf{B N}-\mathbf{H}_{2} \mathbf{S}$ with various biologically relevant species in $\mathrm{PBS}$ ( $\mathrm{pH} 7.4,20 \mathrm{mM}, 5 \% \mathrm{MeOH})$. We selected a serious of small biomolecules and ions that commonly exist in living systems as potential competitive analytes, such as Cys, GSH, $\mathrm{SO}_{3}{ }^{2-}, \mathrm{H}_{2} \mathrm{O}_{2}$. After the addition of $\mathrm{Na}_{2} \mathrm{~S}$, the absorption at $432 \mathrm{~nm}$ appeared obviously, while the absorption spectra of $\mathbf{B N}-\mathbf{H}_{2} \mathbf{S}$ had no marked change upon the addition of other relevant species (Fig. S2†). As shown in Fig. 4, only $\mathrm{Na}_{2} \mathrm{~S}$ can trigger a significantly enhanced fluorescence at $544 \mathrm{~nm}$, while the other relevant species showed no marked influence on the fluorescence spectra of $\mathbf{B N}-\mathbf{H}_{2} \mathbf{S}$. It indicates that $\mathbf{B N}-\mathrm{H}_{2} \mathrm{~S}$ has excellent selectivity for $\mathrm{H}_{2} \mathrm{~S}$ and can be potentially used for detecting $\mathrm{H}_{2} \mathrm{~S}$ in living system.

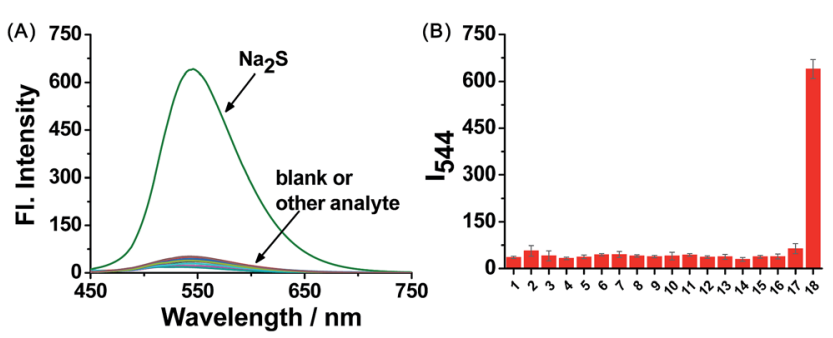

Fig. 4 Fluorescence spectra (A) and fluorescence intensity at $544 \mathrm{~nm}$ (B) of $5 \mu \mathrm{M} \mathrm{BN}-\mathrm{H}_{2} \mathrm{~S}$ to various species in PBS $(\mathrm{pH} 7.4,20 \mathrm{mM}, 5 \%$ $\mathrm{MeOH}$ ) under excitation at 440 nm. 1, blank; 2, GSH; 3, Cys; 4, Hcy; 5 , $\mathrm{FeCl}_{2} ; 6, \mathrm{VC} ; 7, \mathrm{NaF} ; 8, \mathrm{NaBr} ; 9, \mathrm{Nal} ; 10, \mathrm{NaNO}_{2} ; 11, \mathrm{H}_{2} \mathrm{O}_{2} ; 12, \mathrm{NaClO}$; 13, $\mathrm{OH} ; 14, \mathrm{MgCl}_{2} ; 15, \mathrm{ZnCl}_{2} ; 16, \mathrm{NO} ; 17, \mathrm{Na}_{2} \mathrm{SO}_{3} ; 18, \mathrm{Na}_{2} \mathrm{~S}$. Concentration: Cys and GSH, $1 \mathrm{mM}$; the other species, $100 \mu \mathrm{M}$.

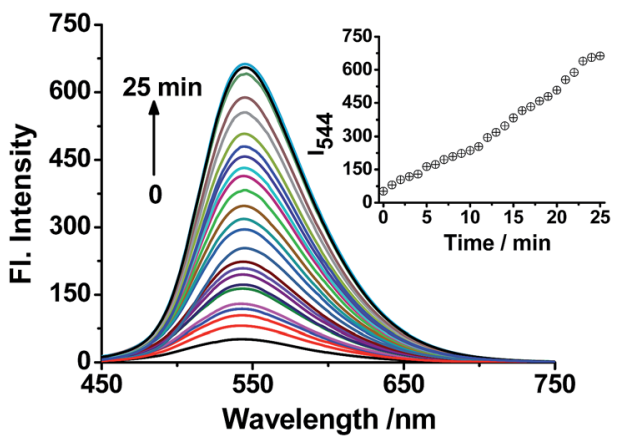

Fig. 5 Time-dependent fluorescence spectra of $5 \mu \mathrm{M} \mathrm{BN}-\mathrm{H}_{2} \mathrm{~S}$ upon addition of $100 \mu \mathrm{M} \mathrm{Na}_{2} \mathrm{~S}$ in PBS ( $\left.20 \mathrm{mM}, \mathrm{pH}=7.4,5 \% \mathrm{MeOH}\right)$ with the excitation at $440 \mathrm{~nm}$, inset: fluorescence intensity at $544 \mathrm{~nm}$ as a function of time.

Time-dependent fluorescence spectra of $\mathbf{B N}-\mathbf{H}_{2} \mathbf{S}$ in the presence of $\mathrm{Na}_{2} \mathrm{~S}$ were studied. Upon the addition of $100 \mu \mathrm{M}$ $\mathrm{Na}_{2} \mathrm{~S}$ to $\mathbf{B N}-\mathbf{H}_{2} \mathrm{~S}$ solution, the fluorescence intensity at $544 \mathrm{~nm}$ increased gradually with time, and reached the maximum within $25 \mathrm{~min}$ (Fig. 5). It indicates that the probe $\mathbf{B N}-\mathbf{H}_{2} \mathbf{S}$ could show response to $\mathrm{H}_{2} \mathrm{~S}$ in a short time. In addition, $\mathbf{B N}$ $\mathbf{H}_{2} \mathbf{S}$ displayed very weak fluorescence in the $\mathrm{pH}$ range of 4.0-10.0 (Fig. S3†). Upon the addition of $\mathrm{Na}_{2} \mathrm{~S}$, the enhanced fluorescence at $544 \mathrm{~nm}$ was observed clearly. However, the fluorescence response of $\mathbf{B N}-\mathbf{H}_{2} \mathbf{S}$ to $\mathrm{Na}_{2} \mathrm{~S}$ tended to occur at weak basic condition, probably because the $\mathrm{H}_{2} \mathrm{~S}\left(\mathrm{p} K_{\mathrm{a} 1}=6.88\right)$ could be ionized to $\mathrm{HS}^{-}$at weak basic condition, which has stronger nucleophilicity relative to $\mathrm{H}_{2} \mathrm{~S}$ and benefits for the reduction of azide group. Considering the physiological $\mathrm{pH}$ of 7.4 and the desirable response of $\mathbf{B N}-\mathbf{H}_{2} \mathbf{S}$ to $\mathrm{H}_{2} \mathrm{~S}$ at this $\mathrm{pH}$, BN- $\mathbf{H}_{2} \mathrm{~S}$ can be potentially used for detecting $\mathrm{H}_{2} \mathrm{~S}$ in living system.

Furthermore, the two-photon properties of $\mathbf{B N}-\mathbf{H}_{2} \mathbf{S}$ in absence and presence of $\mathrm{Na}_{2} \mathrm{~S}$ were investigated by determining its two-photon action spectra $(\delta \Phi)$. As shown in Fig. $6, \mathbf{B N}-\mathbf{H}_{2} \mathbf{S}$ displayed nearly no two-photon property, while it displayed the maximum $\delta \Phi$ values of about $82 \mathrm{GM}$ after the treatment of $\mathrm{Na}_{2} \mathrm{~S}$. It indicates that $\mathbf{B N}-\mathbf{H}_{2} \mathbf{S}$ could be potentially served as a twophoton probe for determining $\mathrm{H}_{2} \mathrm{~S}$ in living systems.

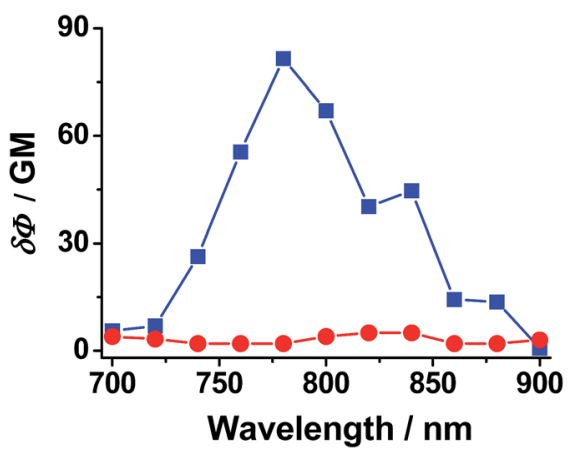

Fig. 6 Two-photon action $(\delta \Phi)$ spectra of $\mathrm{BN}-\mathrm{H}_{2} \mathrm{~S}$ in absence (red) and presence (blue) of $\mathrm{Na}_{2} \mathrm{~S}$ in PBS $(20 \mathrm{mM}, \mathrm{pH}=7.4,5 \%$ $\mathrm{MeOH})$. 


\subsection{Fluorescence imaging of $\mathrm{BN}-\mathrm{H}_{2} \mathrm{~S}$ in living cells}

To confirm the cancer cell-specific capacity of $\mathbf{B N}-\mathbf{H}_{2} \mathbf{S}$ and the two-photon fluorescence response of $\mathbf{B N}-\mathbf{H}_{2} \mathbf{S}$ to $\mathrm{H}_{2} \mathrm{~S}$, the fluorescence imaging experiments were performed in cancer and normal cells, respectively. In consideration of the different expression quantities of biotin receptor on the cell surface, HeLa and NIH 3T3 cells were selected as cancer and normal cell models, respectively. MTT assays indicate that $\mathbf{B N}-\mathbf{H}_{2} \mathbf{S}$ had no marked cytotoxicity for HeLa and NIH 3T3 cells at the concentration of $10 \mu \mathrm{M}$ (Fig. $\mathrm{S} 4 \dagger$ ), and could be suitable for the cell imaging. HeLa and NIH 3T3 cells were incubated with $10 \mu \mathrm{M}$ BN$\mathbf{H}_{2} \mathbf{S}$ for $20 \mathrm{~min}$, and then the cells were incubated with $\mathrm{Na}_{2} \mathrm{~S}$ for another 15 min. As shown in Fig. 7, the HeLa cells treated with only $\mathbf{B N}-\mathbf{H}_{2} \mathrm{~S}$ showed nearly no fluorescence, and displayed strong green fluorescence after the further incubation with $\mathrm{Na}_{2} \mathrm{~S}$ under the one-photon or two-photon excitation. However, when pretreated with $2 \mathrm{mM}$ biotin and further incubated with $\mathbf{B N}-\mathbf{H}_{2} \mathbf{S}$ and

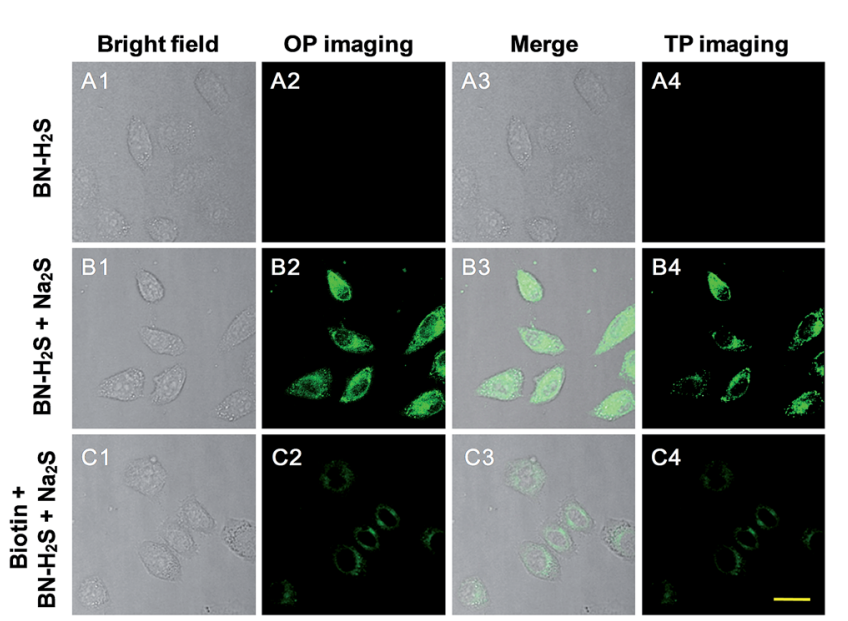

Fig. 7 (A) Fluorescence images of HeLa cells treated with $10 \mu \mathrm{M} \mathrm{BN}$ $\mathrm{H}_{2} \mathrm{~S}$; (B) fluorescence images of HeLa cells treated with $10 \mu \mathrm{M} \mathrm{BN}-\mathrm{H}_{2} \mathrm{~S}$ and $100 \mu \mathrm{M} \mathrm{Na}_{2} \mathrm{~S}$; (C) fluorescence images of HeLa cells pretreated $2 \mathrm{mM}$ biotin and further treated with $10 \mu \mathrm{M} \mathrm{BN}-\mathrm{H}_{2} \mathrm{~S}$ and $100 \mu \mathrm{M} \mathrm{Na}{ }_{2} \mathrm{~S}$. One-photon (OP) imaging: emission at $500-550 \mathrm{~nm}$ with excitation at $488 \mathrm{~nm}$; two-photon (TP) imaging: emission at 500-550 nm with excitation at $760 \mathrm{~nm}$. Scale bar $=20 \mu \mathrm{m}$.

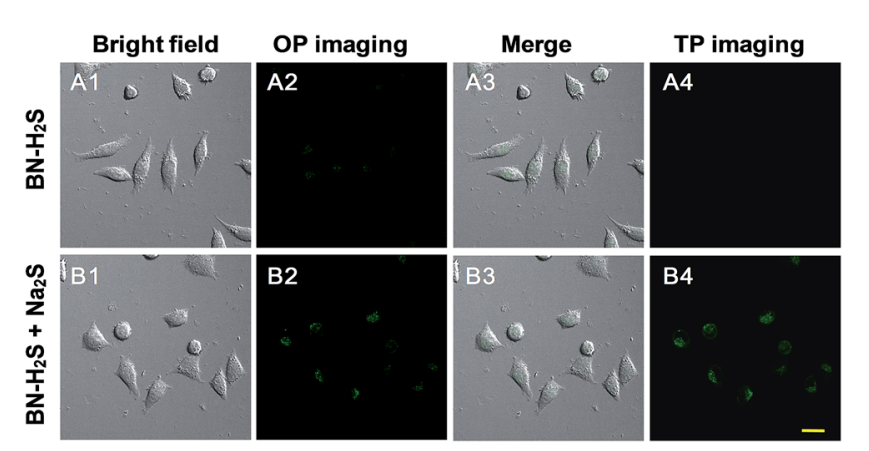

Fig. 8 (A) Fluorescence images of $\mathrm{NIH} 3 \mathrm{~T} 3$ cells treated with $10 \mu \mathrm{M}$ $\mathrm{BN}-\mathrm{H}_{2} \mathrm{~S}$. (B) Fluorescence images of $\mathrm{NIH} 3 \mathrm{~T} 3$ cells treated with $10 \mu \mathrm{M}$ $\mathrm{BN}-\mathrm{H}_{2} \mathrm{~S}$ and $100 \mu \mathrm{M} \mathrm{Na}{ }_{2} \mathrm{~S}$. One-photon (OP) imaging: emission at $500-550 \mathrm{~nm}$ with excitation at $488 \mathrm{~nm}$; two-photon (TP) imaging: emission at $500-550 \mathrm{~nm}$ with excitation at $760 \mathrm{~nm}$. Scale bar $=20 \mu \mathrm{m}$.

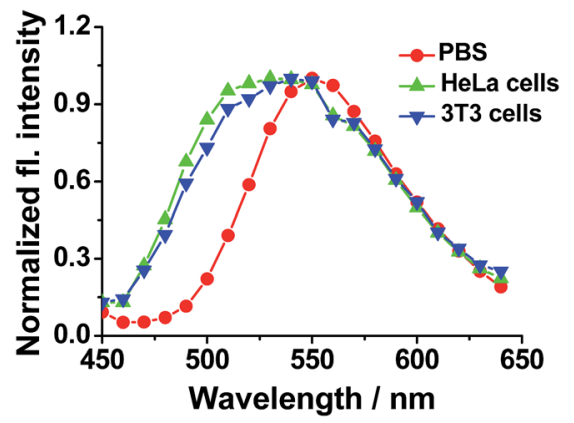

Fig. 9 Normalized two-photon fluorescence spectra $\left(\lambda_{\text {ex }}=760 \mathrm{~nm}\right)$ of $10 \mu \mathrm{M} \mathrm{BN}-\mathrm{H}_{2} \mathrm{~S}$ in presence of $100 \mu \mathrm{M} \mathrm{Na}_{2} \mathrm{~S}$ in PBS $(20 \mathrm{mM}, \mathrm{pH}=7.4$, $5 \% \mathrm{MeOH})$, HeLa cells and $3 T 3$ cells, respectively.

$\mathrm{Na}_{2} \mathrm{~S}$, HeLa cells showed relatively weak fluorescence under the one-photon or two-photon excitation, indicating the biotin can bond to the receptor and then adverse to the cell uptake of $\mathbf{B N}$ $\mathbf{H}_{2}$ S. Meanwhile, compared with HeLa cells, NIH 3T3 cells had weak green fluorescence when treated with $\mathbf{B N}-\mathbf{H}_{2} \mathbf{S}$ and $\mathrm{Na}_{2} \mathrm{~S}$ (Fig. 8). It indicates that the $\mathbf{B N}-\mathbf{H}_{2} \mathbf{S}$ has higher affinity for the HeLa cells, likely because of the higher expression quantity of biotin receptor on the HeLa cell surface relative to NIH 3T3 cell surface. As the control experiments, the $\mathbf{N A}-\mathbf{H}_{2} \mathbf{S}$ which has no biotin group, can be applied for the imaging of $\mathrm{H}_{2} \mathrm{~S}$ in both HeLa and NIH 3T3 cells (Fig. S5 $\dagger$ ). Moreover, under two-photon excitation at $760 \mathrm{~nm}$, the fluorescence peaks at about $540 \mathrm{~nm}$ were observed when $\mathbf{B N}-\mathbf{H}_{2} \mathbf{S}$ responded $\mathrm{H}_{2} \mathrm{~S}$ in PBS, HeLa cells and 3T3 cells, further confirming that the detectable fluorescence in cells can be ascribed to the response of $\mathbf{B N}-\mathbf{H}_{2} \mathbf{S}$ to $\mathrm{H}_{2} \mathrm{~S}$ (Fig. 9). To the best of our knowledge, the cancer cell-specific two-photon probe BN- $\mathbf{H}_{2} \mathbf{S}$ for monitoring $\mathrm{H}_{2} \mathrm{~S}$ in living cells was reported for the first time. Taken together, the $\mathbf{B N}-\mathbf{H}_{2} \mathbf{S}$ can be used as a cancer cell-specific two-photon probe for detecting $\mathrm{H}_{2} \mathrm{~S}$ in living cells.

\section{Conclusions}

In conclusion, we have designed a novel cancer cell-specific twophoton fluorescent probe $\mathbf{B N}-\mathbf{H}_{2} \mathbf{S}$ for detecting $\mathrm{H}_{2} \mathrm{~S}$ in cancer cells. In $\mathbf{B N}-\mathbf{H}_{2} \mathbf{S}$, biotin was selected as the cancer cell-specific group and the azide group was employed as the response site. When $\mathbf{B N}-\mathbf{H}_{2} \mathbf{S}$ responded to $\mathrm{H}_{2} \mathrm{~S}$, the azide group was fast reduced to amide, and the turn-on green fluorescence was observed obviously. The probe exhibited excellent sensitivity with the detection limit of $71 \mathrm{nM}$, and high selectivity for $\mathrm{H}_{2} \mathrm{~S}$ over the other relative species. Under the guidance of biotin group, $\mathbf{B N}-\mathbf{H}_{2} \mathbf{S}$ can be successfully applied for the two-photon imaging of $\mathrm{H}_{2} \mathrm{~S}$ in living cancer cells. We expect that this design concept could be further developed for the detection of other biomolecules in the living cancer cells.

\section{Acknowledgements}

This work was financially supported by NSFC (21472067, 21672083, 51602127), Taishan Scholar Foundation (TS 201511041), and the startup fund of the University of Jinan (309-10004). 


\section{References}

1 R. Wang, Antioxid. Redox Signaling, 2010, 12, 1061-1064.

2 K. Shimamoto and K. Hanaoka, Nitric Oxide, 2015, 46, 72-79.

3 G. D. Yang, L. Y. Wu, B. Jiang, W. Yang, J. S. Qi, K. Cao, Q. Meng, A. K. Mustafa, W. Mu, S. Zhang, S. H. Snyder and R. Wang, Science, 2008, 322, 587-590.

4 B. D. Paul and S. H. Snyder, Nat. Rev. Mol. Cell Biol., 2012, 13, 499-507.

5 J. W. Elrod, J. W. Calvert, J. Morrison, J. E. Doeller, D. W. Kraus, L. Tao, X. Jiao, R. Scalia, L. Kiss, C. Szabo, H. Kimura, C. W. Chow and D. J. Lefer, Proc. Natl. Acad. Sci. U. S. A., 2007, 104, 15560-15565.

6 Y. Kaneko, Y. Kimura, H. Kimura and I. Niki, Diabetes, 2006, 55, 1391-1397.

7 K. Eto, T. Asada, K. Arima, T. Makifuchi and H. Kimura, Biochem. Biophys. Res. Commun., 2002, 293, 1485-1488.

8 K. Abe and H. Kimura, J. Neurosci., 1996, 16, 1066-1071.

9 H. Kimura, Neurochem. Int., 2013, 63, 492-497.

10 K. Fukami, F. Sekiguchi, M. Yasukawa, E. Asano, R. Kasamatsu and M. Ueda, Biochem. Pharmacol., 2015, 97, 300-309.

11 L. Li, M. Bhatia, Y. Z. Zhu, Y. C. Zhu, R. D. Ramnath, Z. J. Wang, F. B. Mohammed Anuar, M. Whiteman, M. Salto-Tellez and P. K. Moore, FASEB J., 2005, 19, 11961198.

12 M. L. Lo Faro, B. Fox, J. L. Whatmore, P. G. Winyard and M. Whiteman, Nitric Oxide, 2014, 41, 38-47.

13 Q. Cao, L. Zhang, G. Yang, C. Xu and R. Wang, Antioxid. Redox Signaling, 2010, 12, 1101-1109.

14 W. J. Cai, M. J. Wang, L. H. Ju, C. Wang and Y. C. Zhu, Cell Biol. Int., 2010, 34, 565-572.

15 V. Kuban, P. K. Dasgupta and J. N. Marx, Anal. Chem., 1992, 64, 36-43.
16 D. M. Tsai, A. S. Kumar and J. M. Zen, Anal. Chim. Acta, 2006, 556, 145-150.

17 C. M. Klingerman, N. Trushin, B. Prokopczyk and P. Haouzi, Am. J. Physiol., 2013, 305, 630-638.

18 M. Nishida, T. Sawa, N. Kitajima, K. Ono, H. Inoue, H. Ihara, H. Motohashi, M. Yamamoto, M. Suematsu, H. Kurose, A. Vliet, B. Freeman, T. Shibata, K. Uchida, Y. Kumagai and T. Akaike, Nat. Chem. Biol., 2012, 8, 714-724.

19 J. R. Lakowicz, Principles of Fluorescence Spectroscopy, Springer, New York, 3rd edn, 2006.

20 Y. Kushida, T. Nagano and K. Hanaoka, Analyst, 2015, 140, 685-695.

21 B. Dong, X. Song, X. Kong, C. Wang, Y. Tang, Y. Liu and W. Lin, Adv. Mater., 2016, 28, 8755-8759.

22 V. S. Lin, W. Chen, M. Xian and C. J. Chang, Chem. Soc. Rev., 2015, 44, 4596-4618.

23 X. Li, X. Gao, W. Shi and H. Ma, Chem. Rev., 2014, 114, 590659.

24 L. Qian, L. Liand and S. Q. Yao, Acc. Chem. Res., 2016, 49, 626-634.

25 K. Zheng, W. Lin, L. Tan, H. Chen and H. Cui, Chem. Sci., 2014, 5, 3439-3448.

26 X. Zhou, F. Su, H. Lu, P. Senechal-Willis, Y. Tian, R. H. Johnson and D. R. Meldrum, Biomaterials, 2012, 33, 171-180.

27 N. S. Makarov, M. Drobizhev and A. Rebane, Opt. Express, 2008, 6, 4029-4047.

28 S. Chen, X. Zhao, J. Chen, J. Chen, L. Kuznetsova, S. S. Wong and I. Ojima, Bioconjugate Chem., 2010, 12, 979-987.

29 Y. H. Lee, Y. Tang, P. Verwilst, W. Lin and J. S. Kim, Chem. Commun., 2016, 52, 11247-11250.

30 L. Zhang, S. Li, M. Hong, Y. Xu, S. Wang, Y. Liu, Y. Qian and J. Zhao, Org. Biomol. Chem., 2014, 12, 5115-5125. 